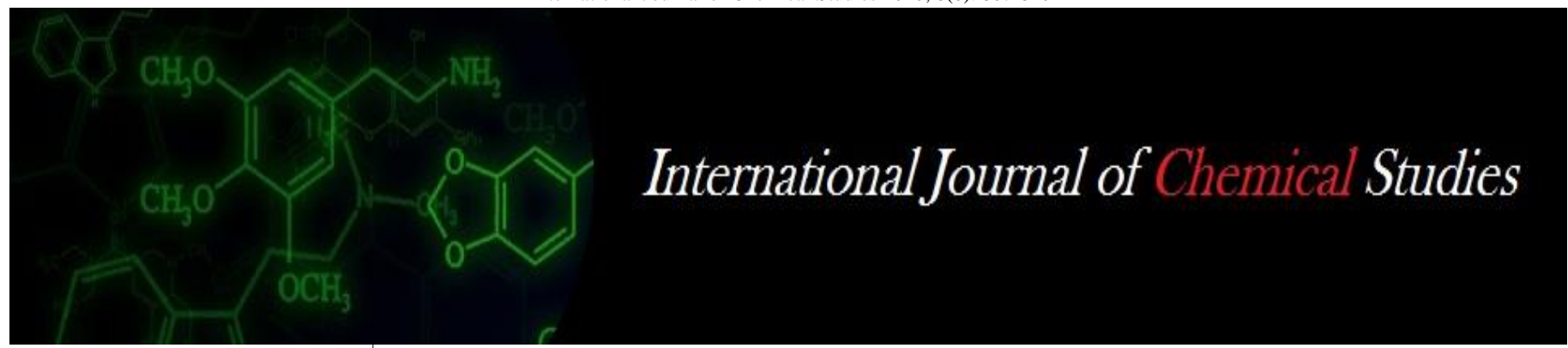

P-ISSN: 2349-8528

E-ISSN: 2321-4902

www.chemijournal.com

IJCS 2020; 8(6): 807-810

(C) 2020 IJCS

Received: 07-09-2020

Accepted: 11-10-2020

Sukanya Ghosh

Assistant Professor, SOA,

GEHU, Dehradun,

Uttarakhand, India

Khushbu Kholiya

Assistant Professor, SOA,

GEHU, Dehradun,

Uttarakhand, India

Rushali Pant

Assistant Professor, SOA,

GEHU, Dehradun,

Uttarakhand, India

\section{Deepak Kholiya}

Associate Professor, SOA,

GEHU, Dehradun,

Uttarakhand, India

\section{Jai Paul}

Professor, COA, GBPUA\&T,

Pantnagar, Uttarakhand, India

Corresponding Author:

Sukanya Ghosh

Assistant Professor, SOA,

GEHU, Dehradun,

Uttarakhand, India

\section{Integrated nutrient management on maize}

\author{
Sukanya Ghosh, Khushbu Kholiya, Rushali Pant, Deepak Kholiya and Jai \\ Paul
}

DOI: $\underline{\text { https://doi.org/10.22271/chemi.2020.v8.i61.10868 }}$

\begin{abstract}
The global food demands of an increasing human population and need for an environment friendly way for sustainable soil plant microbe ecosystem require significant attention when addressing the issue of enhancing agricultural productivity and sustainability. One possible way to enhance crop productivity is by chemical fertilization, but due to unbalanced uses of chemical resources of nutrients in agricultural system affected the soil, food, environmental and human health. But it is not feasible to supply all the nutrient requirements of crops through organic manures due to shortage of their availability and poor quality. So by taking into consideration the above facts, integrated nutrient management (INM) has been developed which involves combined usage of both sources of nutrients to cover all sides. So, a brief impact of INM on maize yield and yield attributes has been discussed below.
\end{abstract}

Keywords: Sustainability, integrated nutrient management, maize, organic

\section{Introduction}

Maize (Zea mays) is one of the most important cereal crops in the world agriculture economy. It is used both as food for human being and feed and fodder for cattle. There is immense potential for uses of maize and hence it occupies a place as queen of cereals. In terms of world acreage, India stands next to U.S.A., Brazil, China and Mexico, while, it ranks eleventh in the respect of production. Maize cultivation in the India mostly confined to the states of Punjab, Haryana, Uttar Pradesh, Madhya Pradesh, Bihar, Maharashtra, Rajasthan, Karnataka, Gujarat, Andhra Pradesh, Tamil Nadu and, Jammu and Kashmir. In India, area and production of maize is about 9.19 million ha and 24.17 million tonnes, respectively with productivity of about 2632 $\mathrm{kg} \mathrm{ha}^{-1}$ during the year 2014-15 (Anonymous, 2016) ${ }^{[2]}$. The high purchase price of chemical nitrogen fertilizer and low purchasing power of Indian farmers restricts its use on proper amounts, hampering crop production. Reliance on the increased and imbalanced use of chemical fertilizers along with its associated hazards has resulted in attention on organic sources of nutrient usage which is effective in promoting health and productivity of the soil and crop productivity. The basic concept of integrated nutrient management is the supply of required plant nutrients for sustaining the desired crop productivity with minimum deleterious effect on soil health environment (Balasubramanian, 1999) ${ }^{[5]}$. With a view to reduce the losses and indiscriminate use of chemical fertilizers, substitution of a part of the chemical fertilizer by locally available organic manures and biofertilizers (Rhizobium and PSB) is inevitable.

\section{Effect of INM on maize yield and yield attributes}

Gundlur et al., 2015 conducted a field experiment in Vertisol of Malaprabha, Karnataka to study the effect of integrated nutrient management in maize. Five years pooled data revealed that significantly higher grain yield $\left(77.60 \mathrm{q} \mathrm{ha}^{-1}\right)$, fodder yield $\left(122.69 \mathrm{q} \mathrm{ha}^{-1}\right)$ and NPK uptake was observed in recommended dose of fertilizer (RDF) plus biofertilizer (Azospirillum + PSB@ $350 \mathrm{~g} \mathrm{ha}^{-1}$ ) with one row of sunhemp between two rows of maize (sunhemp incorporated at 45 days after sowing) as compared to rest of the treatments. However, fifth year results indicated that application of $75 \%$ RDF plus maize stalk incorporation with cellulolytic culture plus biofertilizer (Azospirillum + PSB @ $350 \mathrm{~g} \mathrm{ha}^{-1}$ ) and one row of sunhemp between two rows of maize (sunhemp incorporated at 40 days after sowing) was on par with $100 \%$ RDF in respect of yield and NPK uptake. 
This might be attributed to the addition of higher amount of nutrients through organic and green manures in conjunction with inorganic fertilizer, which resulted in higher maize grain and fodder yield (Balaji et al., 2011) ${ }^{[4]}$.

Hashim et al., $2015^{[12]}$ conducted a field experiment during 2011-12 and 2012-13 at New Delhi, to evaluate the effect of integrated nutrient management on growth and yield attributes, yield and economics of maize (Zea mays L.)-wheat \{(Triticum aestivum (L.) emend. Fiori \& Paol. $\}$ cropping system. The experiment was laid out in a randomized block design during the first year of maize and in factorial randomized block design in successive crops with 3 replications, consisting of 5 different treatments in rainy and winter season each comprising 25 treatment combinations. The results revealed that $50 \%$ recommended dose of fertilizer (RDF-120 kg N, $60 \mathrm{~kg} \mathrm{P}_{2} \mathrm{O}_{5}$ and $\left.40 \mathrm{~kg} \mathrm{~K}_{2} \mathrm{O} \mathrm{ha}^{-1}\right)+50 \%$ recommended dose of nitrogen ( $\mathrm{RDN}-120 \mathrm{~kg} \mathrm{~N} \mathrm{ha}^{-1}$ ) through crop residue mixed farmyard manure resulted in significantly higher maize grain yield $\left(4.24 \mathrm{t} \mathrm{ha}^{-1}\right)$ over the control $(2.23 \mathrm{t}$ $\left.\mathrm{ha}^{-1}\right)$ during first year, but during the second year $\left(5.25 \mathrm{t} \mathrm{ha}^{-1}\right)$ it was significantly higher than the control $\left(3.07 \mathrm{t} \mathrm{ha}^{-1}\right)$ and $50 \% \mathrm{RDF}+25 \% \mathrm{RDN}+$ biofertilizer $\left(4.83 \mathrm{t} \mathrm{ha}^{-1}\right)$. The maximum values of yield attributes were recorded owing to combined application of $50 \% \mathrm{RDF}+50 \% \mathrm{RDN}$ followed by application of $75 \% \mathrm{RDF}+25 \% \mathrm{RDN}$ and these were significantly higher than the control. Maximum cob lengths were recorded with $50 \% \mathrm{RDF}+50 \%$ RDN during both the years. These values were significantly higher than $100 \%$ RDF and the control. The significantly higher values of grains per cob and 1,000 grain weight were recorded with 50\% RDF + $50 \%$ RDN over the control, but at par with the other treatments during both the years. The variation in grain yield across the treatment may be traced to their favourable effects on the growth attributes, which further got translated to yield attributes and finally on grain yield. The integrated nutrient treatments might have resulted in sufficient amount of released nutrients by mineralization at a constant level and increased the nutrient uptake because of the better soil environment created owing to cumulative effect of organic sources combined with inorganic source of nutrients, which improved the plant growth and consequently enhanced the yield attributes and yield (Chauhan, 2010) ${ }^{[6]}$.

Arif et al., 2016 [3] conducted a trial site at the New Developmental Farm of the University of Agriculture, Peshawar and the experiment was started in the summer of 2011.The study consisted of three levels of biochar $(0,25$ and $50 \mathrm{t} \mathrm{ha}^{-1}$ ), two levels of FYM (5 and $10 \mathrm{t} \mathrm{ha}^{-1}$ ) and two levels of fertilizer $\mathrm{N}$ (urea) (75 and $150 \mathrm{~kg} \mathrm{ha}^{-1}$ ) together with a control treatment (no biochar, FYM or fertilizer $\mathrm{N}$ ). The addition of FYM and $\mathrm{N}$ fertilizer significantly increased the yield of maize compared to the unamended control plots. Biochar application significantly increased the grain yield in both years $(P<0.001)$, although there was little difference in grain yield between the $25 \mathrm{tha}^{-1}$ and the $50 \mathrm{tha}^{-1}$ biochar treatments. Biological yield was significantly higher in both years in plots treated with biochar, although the number of grains per cob was only higher in the first year $(P<0.001)$ and an increase in the thousand grain weight was only significantly higher in the second year. The addition of FYM in the treated plots made no significant difference to grain yield in either year, although it did significantly increase the grains per cob, the thousand grain weight and the biological yield in year 1 . Nitrogen fertilizer significantly increased the grain yield and grains per cob in the first year $(P<0.001)$, but this was not repeated in the second year. Two way interactions between the biochar, FYM and the $\mathrm{N}$ fertiliser significantly increased grain yield in the first year $(P<0.05)$, but not the second year, when there was no significant interaction between all three treatments on any of the yield parameters measured.

Jinjala et al., $2016^{[15]}$ conducted a field experiment was during rabi season of 2011-12 on heavy black soil to study the effect of integrated nutrient management on growth and yield of baby corn. The treatments comprising all possible combinations of five levels of nitrogen (chemical and vermicompost fertilizer) with and without biofertilizer (Azotobacter and PSB) were laid out in randomized block design with three replications. It was reported that application of $100 \%$ RDF from chemical fertilizer with biofertilizer to be recorded at various stages as well as days to 50 percent silking and day to first picking and plant height at harvest and it remained statistically at par with $100 \%$ RDN from chemical fertilizer, 25\% RDN from vermicompost and 75\% RDN from chemical fertilizer with biofertilizer, 50\% RDN from vermicompost and 50\% RDN from chemical fertilizer with biofertilizer and 25\% RDN from vermicompost and $75 \%$ RDN from chemical fertilizer. It shows that combined effect of inorganic nutrient application by vermicompost and biofertilizer plays very important role due to their synergetic effect. The nitrogen from fertilizer helped in the promotion of growth during the early stages and while organic sources of nutrients improved crop growth during later stages. The favourable effect of vermicompost on growth might be attributed to presence of relatively readily available plant nutrients, growth enhancing substances and number of beneficial organisms like nitrogen fixing, phosphate solubilising, cellulose decomposing and other beneficial microbes as well as antibiotics, vitamins and hormones etc. (Nehra et al., 2001) ${ }^{[22]}$. Maximum plant height of sweet corn was recorded under recommended dose of fertilizers closely followed by 75 percent recommended dose of $\mathrm{N}+25$ percent $\mathrm{N}$ through vermicompost prepared from Parthanium hysterophorus L. Significantly the highest cobs per plant, cob length, cob girth, cob weight with and without husk were observed with application of $100 \%$ RDN from chemical fertilizer with biofertilizer. Chemical fertilizer and integrated use of fertilizer did bring about significant improvement in overall growth of the crop by providing needed nutrients from initial stage and increase in supply of $\mathrm{N}, \mathrm{P}$ and $\mathrm{K}$ in more synchronize way at the treatment receiving integrated supply of nutrient from organic manure along with inorganic fertilizer and which expressed in terms of plant height, cobs per plant, cob girth, cob length, cob weight with and without husk by virtue of increased photosynthetic efficiency. Thus, greater availability of photosynthates, metabolites and nutrients to develop reproductive structures seems to have resulted in increased productive plants, cob girth, cob length and cob weight with these integrated nutrient management treatments (Thavaprakaash and Velayudham (2007) ${ }^{[30]}$ and Dadarwal et al., 2009) ${ }^{[8]}$.

Mahamood et al., $2016^{[18]}$ conducted a field experiment (2009-2010) at FSRD site Lahirirhat, OFRD, Rangpur during rabi season 2009-2010 to evaluate maximizing maize production through nutrient management. Five treatments viz. $\mathrm{T}_{1} \quad\left(\mathrm{~N}_{300} \mathrm{P}_{50} \mathrm{~K}_{150} \mathrm{~S}_{30}, \quad \mathrm{~T}_{2} \quad\left(\mathrm{P}_{50} \mathrm{~K}_{150} \mathrm{~S}_{30}\right), \quad \mathrm{T}_{3} \quad\left(\mathrm{~N}_{300} \mathrm{~K}_{150} \mathrm{~S}_{30}\right), \quad \mathrm{T}_{4}\right.$ $\left(\mathrm{N}_{300} \mathrm{P}_{50} \mathrm{~S}_{30}\right)$ and $\mathrm{T}_{5}\left(\mathrm{~N}_{300} \mathrm{P}_{50} \mathrm{~K}_{150}\right)$ were evaluated for this purpose. The tallest plant was $(241.7 \mathrm{~cm})$ found from $\mathrm{T}_{1}$ and the shorter plant was recorded from $\mathrm{T}_{2}$ treatment. The highest number of grain $\operatorname{cob}^{-1}$ (493.7) was obtained from $T_{1}$ and the lowest number of grain $\mathrm{cob}^{-1}$ was recorded from $\mathrm{T}_{2}$ treatment. 
The highest 100-grain weight $(32.43 \mathrm{~g})$ was obtained from $\mathrm{T}_{1}$ and the lowest 100 -grain weight $(29.47 \mathrm{~g})$ was recorded from $\mathrm{T}_{2}$ treatment. The highest grain weight $\mathrm{cob}^{-1}(160.0 \mathrm{~g})$ was obtained from $\mathrm{T}_{1}$. Balanced nutrient management application significantly increased maize yield compared to the unbalanced treatment (Achieng et al., 2010) ${ }^{[1]}$. The yield decline to imbalanced and inadequate nutrient application by farmers. Besides, the current nutrient use in the high input maize systems indicates imbalance plant nutrition with very high use of $\mathrm{N}$ and less use of $\mathrm{P}$ and negligible use of $\mathrm{K}$ fertilizers and micronutrients. This has led to nutrient imbalances in soils and lower nutrient use efficiency and economic profitability (Datta et al., 2015 and Detchinli and Sogbedji, 2015) ${ }^{[9,10]}$.

Jadav et al., $2018^{[13]}$ conducted a field experiment during rabi season of 2016 at Jorapura Farm of Livestock Research Station, Sardarkrushinagar Dantiwada Agricultural University, Sardarkrushinagar to study the effect of integrated nutrient management on growth and yield of rabi forage maize (Zea mays L.) The results revealed that $15 \mathrm{t} \mathrm{FYM} \mathrm{ha}^{-1}$ performed better by recording 5.67 and 5 percent higher green forage (503 q ha-1) and dry fodder (105 q ha-1) yield, respectively over $10 \mathrm{t} \mathrm{FYM} \mathrm{ha}^{-1}$. Combined application of $100 \%$ RDF + Azotobacter + PSB performed better by recording 58.23 and 52.63 percent higher green forage $(557 \mathrm{q}$ $\left.\mathrm{ha}^{-1}\right)$ and dry fodder $\left(116 \mathrm{q} \mathrm{ha}^{-1}\right)$ yield over other treatments. The results revealed that application of $15 \mathrm{t} \mathrm{FYM} \mathrm{ha}^{-1}$ performed better by recording higher plant height $(165.9 \mathrm{~cm})$, number of leaves per plant (12.6), stem girth of 3rd internode $(7.96 \mathrm{~cm})$, leaf area per plant $\left(3624 \mathrm{~cm}^{2}\right)$, leaf: stem ratio (0.34) and length of internodes $(12.1 \mathrm{~cm})$ respectively over application of $10 \mathrm{t}$ FYM ha-1. Combined application of $100 \%$ $\mathrm{RDF}+$ Azotobacter + PSB recorded higher values of plant height $(175.8 \mathrm{~cm})$, number of leaves per plant $(13.5)$, stem girth of 3rd internode $(9.28 \mathrm{~cm})$, leaf area per plant $(4000$ $\left.\mathrm{cm}^{2}\right)$, leaf:stem ratio $(0.37)$ and length of internodes $(12.7 \mathrm{~cm})$ over other combinations. This might be due to additional amount of nutrient supplied as well as beneficial effects of decomposed organic matter that derived in connection with physicochemical properties of the soil (Mukherjee, 2014 and Kumar et al., 2015) [21, 17]. Also an improve in all growth parameter viz., plant height, number of leaves, stem girth of 3rd internode, leaf area per plant, leaf: stem ratio, length of internode and availability of nutrients at every crop growth stage in adequate amount and slow release of primary and secondary nutrients which increase green forage yield and increase in green forage yield with application of farm yard manure similarly increase in dry forage yield (Vadivel et al., 2001, Pathak et al., 2005 and Verma et al., 2016) ${ }^{[31,26,32] .}$

Jat et al., $2018^{[14]}$ reported that the effect of TRL (tillage, residue and legume mung bean) treatments on 1000-grain weight was nonsignificant. $\mathrm{PB}+\mathrm{MB}$ (permanent beds with mung bean) recorded significantly higher mean (over 3 yrs) cob length, cob weight, and grains $\mathrm{cob}^{-1}$ compared to CT (conventional tillage). SSNM (site specific nutrient management) resulted in significantly higher cob length, cob weight, grains $\mathrm{cob}^{-1}$ and 1000-grain weight compared to RDF and FFP (farmer's fertilizer practice). Maize yield was 6.9, 7.7 and $14.4 \%$ higher under $\mathrm{PB}+\mathrm{MB}$ compared to CT during year 2012-13, 2013-14 and 2014-15, respectively and it was at par with PB (permanent beds) in all the three years. Maize grain yield (3 years mean) was increased by 3.0 and $6.8 \%$ with $\mathrm{CT}+\mathrm{MB}$ (conventional tillage with mung bean) and $\mathrm{PB}$ compared to $\mathrm{CT}$, respectively. Among NM (nutrient management strategies) treatments, $0.37,0.57$ and $0.18 \mathrm{Mg}$ ha $^{-1}$ of higher maize yield was recorded under SSNM compared to RDF in 2012, 2013 and 2014, respectively. The maize yield under FFP treatment was 9.7, 13.9 and $6.8 \%$ lower compared to SSNM during 2012, 2013 and 2014, respectively. Mean grain yield (averaged over 3 years) was 5.3 and $10.5 \%$ higher with RDF and SSNM compared to FFP, respectively. Maize yield increased significantly with SSNM under all TRL and it was higher in $\mathrm{PB}+\mathrm{MB}$ than under other TRL treatments. The higher yield of maize with PB might be due to compound effect of improved soil health (Singh et al., 2016) ${ }^{[23,24]}$, better water regimes (Ram et al., 2010) ${ }^{[27]}$, lesser weed population (Chauhan et al., 2007) ${ }^{[7]}$ and site specific nutrient management (Parihar et al., 2017b) ${ }^{[25]}$. The increase in grain yields of maize on PB in comparison to CT system was attributed to increase in yield attributes such as number of cobs plant ${ }^{-1}$, cob length and grain weight in maize (Parihar et al., 2016b) ${ }^{[23]}$. Furthermore, residue mulch in PB provided favorable soil moisture and temperature conditions for better crop growth resulting in higher grain yields of maize. Among the nutrient management strategies, nutrient expert based SSNM gave higher crop yields than RDF and FFP. The SSNM provides an approach to feeding crops with nutrients as and when they are needed (Kumar et al., 2012 and Satyanarayana et al., 2013) ${ }^{[16,28]}$. It ensures that all the required nutrients are applied at the proper rate and in proper ratio based on the crop's nutrient needs (Majumdar et al., 2012) ${ }^{[19]}$, which ultimately led to higher yields of maize (Parihar et al., 2017a) ${ }^{[24]}$.

\section{Conclusion}

The practice of INM includes all possible sources of plant nutrients to optimize nutrient inputs, spatial and temporal matching of the soil nutrient supply with crop demand and reducing $\mathrm{N}$ losses while improving crop yield. Balanced use of organic manures will be of fundamental importance for crop productivity and environmental concerns, which should be a priority for INM practices, provides a "win-win" opportunity to simultaneously increase crop productivity and agricultural sustainability.

\section{References}

1. Achieng JO, Ouma G, Odhiambo G, Muyekho F. Effect of farmyard manure and inorganic fertilizers on maize production on Alfisols and Ultisols in Kakamega, western Kenya. Agriculture and Biology Journal of North America 2010;1(4):430-439.

2. Anonymous 2016. www. indistat.com

3. Arif M, Ali K, Jan MT, Shah Z, Jones DL, Quilliam RS. Integration of biochar with animal manure and nitrogen for improving maize yields and soil properties in calcareous semi-arid agroecosystems. Field Crops Research 2016;195: 28-35.

4. Balaji ML, Verma A, Neepalla V, Kanthaliya PC. Productivity and quality of maize (Zea mays L.) as influenced by integrated nutrient management under continuous cropping and fertilization. Indian Journal Agricultural Sciences 2011;81:374-376.

5. Balasubramanian V. Managing soil quality for sustainable rice production. Tamil Nadu Rice Research Institute, Anuthrai, $4^{\text {th }}$ International Crop Science Congress, 1999,11-24.

6. Chauhan NM. Effect of integrated nutrient management on growth, yield and economics of sweet corn (Zea mays L). Journal of Progressive Agriculture 2010;1(1):8-10. 
7. Chauhan BS, Gill GS, Preston C. Effect of seeding systems and dinitroaniline herbicides on emergence and control of rigid ryegrass (Lolium rigidum) in wheat. Weed Technology 2007;21(1):53-58.

8. Dadarwal RS, Jain NK, Singh D. Integrated nutrient management in baby corn (Zea mays). Indian Journal of Agricultural Science 2009;79:1023-1025.

9. Datta A, Shrestha S, Ferdous Z, Win CC. Strategies for enhancing phosphorus efficiency in crop production systems. In: A. Rakshit, H.B. Singh, and A. Sen (Eds.), Nutrient Use Efficiency: from Basics to Advances. Springer, ISBN 978-81-322-2169-2 2015, 59-71.

10. Detchinli KS, Sogbedji JM. Yield performance and economic return of maize as affected by nutrient management strategies on feralsols in coastal western Africa. European Scientific Journal 2015;11(27):312324.

11. Gundlur SS, Patil PL, Rajkumara S, Ashoka P, Neelakantha JK. Influence of integrated nutrient management on yield and uptake of nutrients by maize and soil fertility under irrigated conditions in Vertisol. Karnataka Journal of Agricultural Sciences 2015;28(2):172-175.

12. Hashim M, Dhar S, Vyas AK, Pramesh V, Kumar B. Integrated nutrient management in maize (Zea mays)wheat (Triticum aestivum) cropping system. Indian Journal of Agronomy 2015;60(3):352-359.

13. Jadav VM, Patel PM, Chaudhari JB, Patel JM, Chaudhari PP. Effect of integrated nutrient management on growth and yield of rabi forage maize (Zea mays L.). International Journal of Chemical Studies 2018;6(1):2160-2163.

14. Jat RD, Jat HS, Nanwal RK, Yadav AK, Bana A, Choudhary KM et al. Conservation agriculture and precision nutrient management practices in maize-wheat system: effects on crop and water productivity and economic profitability. Field Crops Research 2018;222:111-120.

15. Jinjala VR, Virdia HM, Saravaiya NN, Raj AD. Effect of integrated nutrient management on baby corn (Zea mays L.). Agricultural Science Digest-A Research Journal 2016;36(4):291-294.

16. Kumar A, Majumdar K, Jat ML, Pampolino M, Kamboj BR, Bishnoi DK et al. Evaluation of nutrient expert TM for wheat. Better Crops-South Asia 2012;6:27-29.

17. Kumar R. Productivity, profitability and nutrient uptake of maize (Zea mays L.) as influenced by management practices in North-East India. Indian Journal of Agronomy 2015;60(2):273-278.

18. Mahamood NU, Ferdous Z, Anwar M, Ali R, Sultana M. Yield maximization of maize through nutrient management. Progressive Agriculture 2016;27(4):428434.

19. Majumdar K, Jat ML, Shahi VB. Effect of spatial and temporal variability in cropping seasons and tillage practices on maize yield responses in eastern India. Better Crops South Asia 2012;6(1): 8-10.

20. Manjaiah SS, KM, Pal S, Singh AK. Soil carbon fractions under maize-wheat system: effect of tillage and nutrient management. Environmental monitoring and assessment 2016;188(1): 14 .

21. Mukherjee D. Influence of integrated nutrient management on productivity, nutrient uptake and economics of maize (Zea mays L.) - yellow sarson (Brassica rapa) cropping system under rainfed mid hill condition. Indian Journal of Agronomy 2014;59(2):221228.

22. Nehra AS, Hooda IS, Singh KP. Effect of integrated nutrient management on growth and yield of wheat (Triticum aestivum). Indian Journal of Agronomy 2001;46:112-117.

23. Parihar CM, Jat SL, Singh AK, Kumar B, Pradhan S, Pooniya $\mathrm{V}$ et al. Conservation agriculture in irrigated intensive maize-based systems of north-western India: effects on crop yields, water productivity and economic profitability. Field Crops Research 2016;193:104-116.

24. Parihar CM, Jat SL, Singh AK, Majumdar K, Jat ML, Saharawat YS et al. Bio-energy, water-use efficiency and economics of maize-wheat-mungbean system under precision-conservation agriculture in semi-arid agroecosystem. Energy 2017;119:245-256.

25. Parihar CM, Jat SL, Singh AK, Ghosh A, Rathore NS, Kumar B, et al. Effects of precision conservation agriculture in a maize-wheat-mungbean rotation on crop yield, water-use and radiation conversion under a semiarid agro-ecosystem. Agricultural Water Management 2017;192:306-319.

26. Pathak SK, Singh SB, Jha RN, Sharma RP. Effect of nutrient management on nutrient uptake and changes in soil fertility in maize (Zea mays L.) - wheat (Triticum aestivum) cropping system. Indian Journal of Agronomy 2005;50(4):269-273.

27. Ram H, Kler DS, Singh Y, Kumar K. Productivity of maize (Zea mays)-wheat (Triticum aestivum) system under different tillage and crop establishment practices. Indian Journal of Agronomy 2010;55(3):185190.

28. Satyanarayana T, Majumdar K, Pampolino M, Johnston AM, Jat ML, Kuchanur P et al. Nutrient Expert: a tool to optimise nutrient use and improve productivity of maize. Better Crops 2013;97(1):21-24.

29. Singh VK, Shukla AK, Singh MP, Majumdar K, Mishra $\mathrm{RP}$, Rani $\mathrm{M}$ et al. Effect of site-specific nutrient management on yield, profit and apparent nutrient balance under pre-dominant cropping systems of Upper Gangetic Plains. Indian Journal of Agricultural Sciences, 2015;85(3):335-343.

30. Thavaprakaash N, Velayudham K. Effect of crop geometry, intercropping system and INM practices on cob yield and nutrient uptake of baby corn. Asian journal of Agricultural Research 2007;1:10-16.

31. Vadivel N, Subbian P, Velayutham A. Effect of integrated nitrogen - management practices on the growth and yield of rainfed winter maize (Zea mays L.). Indian Journal of Agronomy 2001;46(2):250-254.

32. Verma C, Thanki JD, Singh D, Chaudhari SN. Effect of nitrogen, biofertilizer and farm yard manure on yield and nutrient uptake in oat (Avena sativa L.). The Bioscan. An International Quarterly Journal of Life Sciences 2016;11(1):499-501. 